\title{
PENYULUHAN PENGELOLAAN SISTEM PEMELIHARAAN DAN KESEHATAN PADA SAPI PERAH DI KELOMPOK TERNAK WIBAWA MEKAR, DESA GUNUNG MANIK, SUMEDANG, JAWA BARAT
}

\author{
Sarasati Windria ${ }^{1 *}$, Nadia Nuraniya Kamaluddin ${ }^{2}$, Arifudin Achmad ${ }^{3}$, dan Okta Wismandanu ${ }^{4}$ \\ ${ }^{1}$ Program Studi Kedokteran Hewan, Divisi Mikrobiologi, Departemen Ilmu Kedokteran Dasar, Pusat Studi Infeksi, \\ Fakultas Kedokteran, Universitas Padjadjaran \\ ${ }^{2}$ Departemen Ilmu Tanah dan Sumberdaya Lahan, Fakultas Pertanian, Universitas Padjadjaran \\ ${ }^{3}$ Departemen Kedokteran Nuklir dan Pencitraan Molekuler, Fakultas Kedokteran, Universitas Padjadjaran \\ ${ }^{4}$ Program Studi Kedokteran Hewan, Departemen Kesehatan Masyarakat, Fakultas Kedokteran, Universitas Padjadjaran \\ E-mail: sarasati.windria@unpad.ac.id
}

\begin{abstract}
ABSTRAK. Kesehatan ambing merupakan faktor penting dalam usaha peternakan sapi perah. Kerugian yang ditimbulkan ketika kesehatan ambing tidak terjaga adalah munculnya kasus mastitis atau sering disebut dengan mastitis. Ternak yang terinfeksi mastitis akan mengalami penurunan kualitas dan kuantitas susu sehingga berdampak pula terhadap pendapatan ekonomi peternak. Kasus mastitis yang sering terjadi pada ternak adalah mastitis subklinis. Mastitis subklinis merupakan radang pada ambing yang terjadi tanpa disertai kemunculan gejala klinis namun kualitas dan kuantitas susu yang dihasilkan menurun secara drastis. Tingginya angka kejadian mastitis subklinis mendorong untuk dilakukan penyuluhan mengenai pengelolaan sistim pemeliharaan dan kesehatan pada sapi perah sebagai upaaya pencegahan kasus mastitis.Metode pengukuran keberhasilan penyuluhan melalui penghitungan statistik persentase hasil quisioner yang dilakukan sebelum dan sesudah penyuluhan. Topik quisioner yang diambil adalah pemahaman masyarakat terhadap kasus mastitis serta faktor - faktor yang mempengaruhi kesehatan ambing. Rangkaian kegiatan penyuluhan ini sebagai upaya untuk menekan angka kejadian mastitis melalui peningkatan pemahaman masyarakat. Hasil dari penyuluhan ini adalah peningkatan pengetahuan peternak sebesar 20,8\% mengenai definisi, gejala klinis serta faktor-faktor resiko yang dapat menimbukan mastitis
\end{abstract}

Kata kunci: mastitis; kesehatan; sapi perah; sumedang; pemeliharaan; penyuluhan

\begin{abstract}
Udder health is an important factor in dairy farming business. Losses caused when udder health is not maintained is the emergence of cases of mastitis or often referred to as mastitis. Livestock infected with mastitis will experience a decrease in the quality and quantity of milk so that it also affects the economic income of farmers. Cases of mastitis that often occur in cattle is subclinical mastitis. Subclinical mastitis is an inflammation of the udder that occurs without the appearance of clinical symptoms but the quality and quantity of milk produced drastically decreases. The high incidence of subclinical mastitis encourages counseling regarding the management of the maintenance and health system in dairy cows as an effort to prevent mastitis cases. The method of measuring the success of counseling through statistical calculation of the percentage of the results of the questionnaire conducted before and after counseling. The questionnaire topic taken was people's understanding of mastitis cases as well as factors affecting udder health. The series of outreach activities as an effort to reduce the number of mastitis events through increased public understanding. The result of this counseling was an increased farmer's knowledge by $20.8 \%$ regarding the definition, clinical symptoms and risk factors that can caused mastitis
\end{abstract}

Key words: mastitis; health; dairy cows; sumedang; maintenance; counseling

\section{PENDAHULUAN}

Susu merupakan salah satu sumber protein hewani yang memiliki banyak manfaat bagi tubuh manusia. Kualitas dan kuantitas produksi susu yang baik ditunjang oleh sistim pemeliharaan sapi yang baik. Kasus penyakit yang sering muncul akibat sistim pemeliharaan sapi perah yang kurang baik adalah mastitis atau radang pada ambing. Mastitis atau radangambing sering menyerang sapi-sapi perah baik milikperusahaan maupun sapi perah milik peternak kecil yangbanyak menimbulkan kerugian. Kejadian mastitis padasapi perah di Indonesia sangat tinggi yaitu mencapai85\% dengan angka kerugian ekonomi yang cukup tinggi. Kecamatan Tanjungsari memiliki banyak peternakan sapi perah yang terbagi menjadi beberapa kelompok ternak. Kelompok Ternak Wibawa Mekar adalah salah satu kelompok ternak yang memiliki angkalaporan kejadian mastitis yang tinggi (Pisestyani, dkk., 2017; Guimarães et al., 2017).

Kejadian ini sebagian besar merupakan infeksi subklinis sehingga tidak cepat dilakukan penanganan atau pun pengendalian. Dampak kerugian penyakit mastits adalah penurunan kualitas dan kuantitas susu. Pengelolaan sistim pemeliharaan kesehatan pada sapi perah meliputi sistim manajemen perkandangan dan pakan, sistim manajemen pemerahan dan sanitasi lingkungan perkandangan (Fávero et al., 2015). Komponen penting yang berperan dalam terwujudnya kualitas dan kuantitas susu yang baik adalah manajemen pemliharaan sapi, sanitasi perkandangan dan higienitas pemerah (Verhaeghe et al., 2015). Sumedang merupakan kabupaten yang terletak di Jawa barat memiliki jumlah populasi sapi perah yang besar dan berpotensi mengalami mastitis (Badan Pusat Statistik, 2018). Faktor - faktor resiko munculnya kasus mastitis penting untuk diteliti sebagai upaya pencegahan. Data yang diperoleh dari pengabdian ini diharapkan menjadi dasar untuk dilakukan penelitian lanjutan mengenai mastitis sehingga dalam jangka panjang dapat meningkatkan kualitas dan kuantitas produksi susu sapi secara nasional.

\section{METODE}

Metode yang digunakan daalam pengabdian ini melalui beberapa tahapan yaitu: 1.) Survey pengetahuan 
peternak sapi mengenai mastitis, 2.) Penyuluhan dan 3.) Surveypost penyuluhan pengetahuan peternak sapi mengenai pemahaman teori yang diberikan saat penyuluhan. Pengabdian dan penelitian dilakukan di Kelompok ternak "Wibawa Mekar", Kecamatan Pamulihan, KabupatenSumedang, Jawa Barat. Jumlah responden survey kuisioner sebanyak 50 orang.

Metode sosialisasi/ peyuluhanyang digunakan untuk penyuluhan adalah menggunakan alat peraga berupa slide power pointyang berisikan materi umum, video mengenai metode deteksi dini mastitis subklinis menggunakanCalifornia Mastitis Test (CMT) serta tanya jawab seputar materi yang telah disampaikan. Indikator keberhasilan program pengabdian diukur menggunakan persentase hasil survey angket kuisioner post penyuluhan. Angket kuisioner berisikan dua komponen pertanyaan yaitu: a.) Pemahaman peternak mengenai definisi dan gejala klinis mastits, b.)Penerapan teori secara aplikatif sistim pemeliharaan sapi perah. Metode pengukuran keberhasilan program penyuluhan melalui penghitungan persentase hasil kuisioner pre-penyuluhan dan postpenyuluhan menggunakan microsoftexcel 2013. Signifikansi persentase keberhasilan dianalisis secara statistik menggunakan uji Wilcoxon $\mathrm{p}>0.05$.

\section{HASIL DAN PEMBAHASAN}

Desa Gunungmanik merupakan sebuah desa yang berada di wilayah Kecamatan Tanjungsari Kabupaten Sumedang. Lokasinya berada di bagian timur wilayah kecamatan dan berbatasan langsung dengan Kecamatan Pamulihan. Jaraknya dengan pusat kecamatan sekitar tiga kilometer.Secara topografis, wilayah Desa Gunungmanik memiliki bentang permukaan tanah berupa dataran dengan ketinggian wilayah dimana kantor desa berada sekitar 871 meter di atas permukaan laut. Secara geografis, Desa Gunungmanik dikelilingi oleh wilayah-wilayah sebagai berikut: Desa Ciptasari Kecamatan Pamulihan di sebelah utara, Desa Haurngombong dan Desa Mekarbakti (keduanya berada di Kecamatan Pamulihan) di sebelah timur, Desa Raharja di sebelah selatan, serta Desa Margajaya di sebelah baratnya.

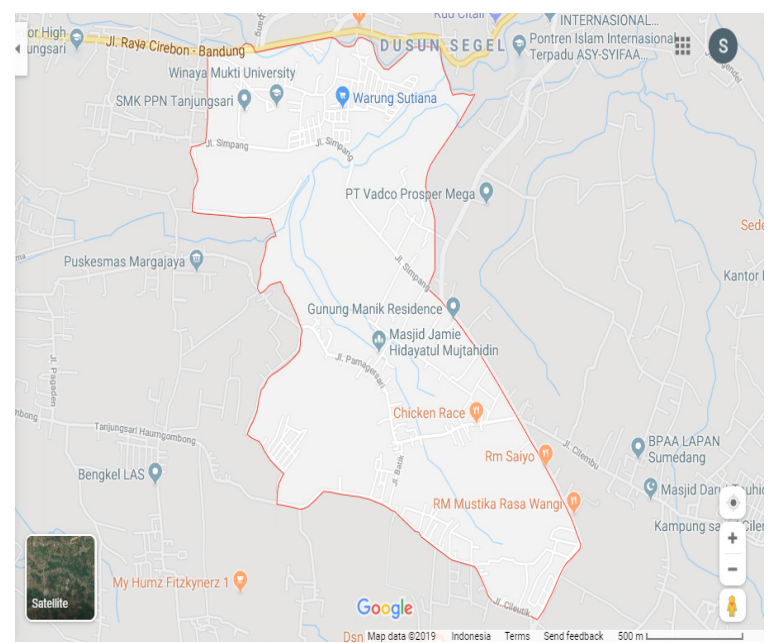

Gambar 1.Area Desa Gunungmanik, Kecamatan Pamulihan Kabupaten Sumedang, Jawa Barat

(Sumber : Google maps, 2018)
Anggota kelompok ternak "Wibawa Mekar" yang mengikuti seluruh rangkaian program penyuluhan sebanyak 24 orang dengan jumlah populasi sapi sebesar \pm 168 ekor. Data hasil angket kuisioner mengenai tingkat pengetahuan peternak mengenai mastitis sebelum dan sesudah penyuluhan tersaji dalam tabel 1. Data hasil angket kuisioner mengenai penerapan teori secara aplikatif sistim pemeliharaan sapi perah yang baik tersaji dalam tabel 2 .

Tabel 1. Data hasil angket kuisioner tingkat pengetahuan peternak mengenai mastitis di kelompok "Wibawa Mekar" Kabupaten Sumedang, Jawa Barat.

\begin{tabular}{lcccc}
\hline $\begin{array}{c}\text { Kategori } \\
\text { Pengetahuan }\end{array}$ & $\begin{array}{c}\text { Pre- } \\
\text { Penyuluhan }\end{array}$ & $\begin{array}{c}\text { Persentase } \\
(\%)\end{array}$ & $\begin{array}{c}\text { Post- } \\
\text { Penyuluhan }\end{array}$ & $\begin{array}{c}\text { Persentase } \\
(\%)\end{array}$ \\
\hline Buruk & 7 & 29,2 & 3 & 12,5 \\
Sedang & 7 & 29,2 & 6 & 25 \\
Baik & 10 & $\mathbf{4 1 , 7}$ & 15 & $\mathbf{6 2 , 5}$ \\
Total & 24 & 100 & 24 & 100 \\
\hline
\end{tabular}

Tabel 2. Data hasil angket kuisioner mengenai penerapan teori secara aplikatif sistim pemeliharaan sapi perah di kelompok "Wibawa Mekar", kabupaten Sumedang, Jawa Barat

\begin{tabular}{lcccc}
\hline $\begin{array}{c}\text { Kategori } \\
\begin{array}{c}\text { Penerapan } \\
\text { teori secara } \\
\text { aplikatif }\end{array}\end{array}$ & $\begin{array}{c}\text { Pre- } \\
\text { Penyuluhan }\end{array}$ & $\begin{array}{c}\text { Persentase } \\
(\%)\end{array}$ & $\begin{array}{c}\text { Post- } \\
\text { Penyuluhan }\end{array}$ & $\begin{array}{c}\text { Persentase } \\
(\%)\end{array}$ \\
\hline Buruk & 6 & 25 & 6 & 25 \\
Sedang & 8 & 33,3 & 8 & 33,3 \\
Baik & 10 & $\mathbf{4 1 , 7}$ & 10 & $\mathbf{4 1 , 7}$ \\
Total & 24 & 100 & 24 & 100 \\
\hline
\end{tabular}

Keberhasilan penyuluhan ini dapat dilihat dari hasil suervey angket kuisioner post penyuluhan. Tingkat pengetahuan peternak terhadap mastitis beserta faktorfaktor yang mempengaruhinya mengalami peningkatan namun tidak signifikan secara statistik (Uji Wilcoxon $\mathrm{p}>0.05$ ) Peternak menunjukkan respon yang postif terhadap penyuluhan ini yang terlihat dengan peningkatan pengetahuan namun belum diterapkan secara langsung pada ternak. Peningkatan perbaikan sikap dapat terwujud dalam kurun waktu observasi yang lebih lama. Penghambat dari keberhasilan penyuluhan ini adalah diperlukan sarana dan prasarana yang mendukung untuk mengaplikasikan teori manajemen pemeliharaan sapi perah. Pendampingan kesehatan lanjutan oleh dokter hewan dan paramedisdiperlukan sebagai tindak lanjut penyuluhan sehingga pencegahan dan penanganan kasus mastitis dapat ditangani dengan baik.

Penyuluhan ini dapat terlaksana dengan baik berkat kerjasama bebbagai pihak diantaranya cititas akademika universitas padjadjaran, koperasi serba usaha Tanjungsari serta mahasiswa KKN Unpad 2019. Keterlibatann mahasiswa sebagai sarana interaksi langsung antara mahasiswa kepada masyarakat. Observasi lingkungan serta interaksi langsung dengan masyarakat mendorong mahasiswa untuk dapat memberikan ilmu yang telah dipelajari, serta mengetahui kondisi real di lapangan tentang fakta apa saja yang terjadi dibutuhkan masyarakat sesuai dengan bidang 
keilmuan masing - masing. Hasil dari observasi, interaksi dan penyuluhan dapat dijadikan bekal mahasiswa untuk meningkatkan Ilmu Pengetahuan dan Teknologi (IPTEk).

\section{SIMPULAN}

Penyuluhan mengenai pengelolaan sistim pemeliharaan dan kesehatan pada sapi perah di Kelompok ternak "Wibawa Mekar", Desa Gunung manik, Kecamatan Pamulihan, Kabupaten Sumedang Jawa Barat bejalan dengan lancar. Dampak dari penyuluhan ini adalah peningkatan pengetahuan peternak sebesar 20,8\% mengenai definisi, gejala klinis serta faktor-faktor resiko yang dapat menimbukan mastitis.Saran dari penyuluhan ini adalah perlu dilakukan pendampingan serta observasi hasil produksi susu dan angka kejadian mastitis yang lebih lama kepada peternak terhadap perbaikan aplikasi secara langsung penerapan teori yang telah diberikan saat penyuluhan

\section{UCAPAN TERIMAKASIH}

Ucapan terimakasih penulis sampaikan kepada Direktorat Riset, Pengabdian Kepada Masyarakat, dan Inovasi (DRPMI) Universitas Padjadjaran yang telah mendanai penelitian ini sehingga bisa berjalan dengan baik. Ucapan terima kasih juga penulis sampaikan kepada KSU "Tandangsari" dan kelompok ternak "Wibawa Mekar" yang telah menjadi mitra dalam pelaksanaan penelitian ini.

\section{DAFTAR PUSTAKA}

Badan Pusat Statistik, (2018). Kecamatan Tanjugsari dalam angka 2017. Badan Pusat Statistik, Jakarta. https://www.bps.go.id.

Fávero, S., Portilho, F.V.R., Oliveira, A.C.R., Langoni, H. \& Pantoja, J.C.F., (2015). Factors associated with mastitis epidemiologic indexes, animal hygiene, and bulk milk bacterial concentrations in dairy herds housed on compost bedding. Livestock Science, 181, 220-230.

Guimarães, J.L., Brito, M.A., Lange, C.C., Silva, M.R., Ribeiro, J.B., Mendonça, L.C., Mendonça, J.F. \& Souza, G.N. (2017). Estimate of the economic impact of mastitis: A case study in a Holstein dairy herd under tropical conditions. Preventive veterinary medicine, 142, 46-50.

Pisestyani, H., Sudarnika, E., Ramadhanita, R., Ilyas, A.Z., Basri, C., Wicaksono, A., Nugraha, A.B. \& Sudarwanto, M.B., (2017). Perlakuan Celup Puting setelah Pemerahan terhadap Keberadaan Bakteri Patogen, Staphylococcus aureus, Streptococcus agalactiae, dan E. coli pada Sapi Perah Penderita Mastitis Subklinis di Peternakan KUNAK Bogor. Jurnal Sain Veteriner, 35, (1), 63-70.

Verhaeghe, J., 2015. Hygiene for health: production. The Dairy Mail, 22, (3), 55-61. 